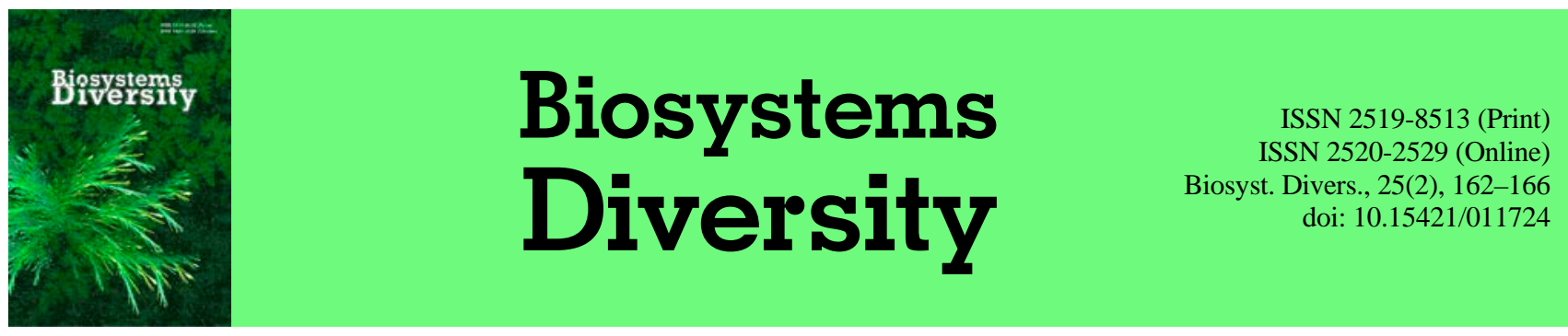

\title{
Changes in the viability of the eggs of Ascaris suum under the influence of flavourings and source materials approved for use in and on foods
}

\author{
A. A. Boyko*, V. V. Brygadyrenko** \\ *Dnipro State Agrarian-Economic University, Dnipro, Ukraine \\ **Oles Honchar Dnipro National University, Dnipro, Ukraine
}

\begin{abstract}
Article info
Received 19.03.2017

Received in revised form 07.05.2017

Accepted 10.05.2017
\end{abstract}

Dnipro State Agrarian-Economic University, Sergey Efremov Str., 25, Dnipro, 49600, Ukraine. Tel.: +38-099-405-51-98

E-mail:

boikoalexandra1982@gmail.com

Oles Honchar Dnipro National University, Gagarin Ave., 72, Dnipro, 49010, Ukraine.

Tel.: +38-050-939-07-88

E-mail:brigad@ua/fm

\section{Introduction}

Swine rearing is one of promising and developed spheres of livestock breeding in the world, and in Ukraine in particular (Feshenko, 2008; Evstafieva, 2010). There are a number of factors which negatively affect its development. First of all, these factors include parasitic diseases, such as ascariasis, trichocephalosis, oesophagostomiasis, strongyloidiasis, echinococcosis, cysticercosis, sarcoptosis, balantidiasis and others. The most widespread disease of pigs globally is ascariasis (De Velásquez et al., 2004; Feshenko, 2008; Evstafieva, 2010; Katakam et al., 2016). It causes great damage to swine-rearing. The prevalence of the disease on pig farms can reach $100 \%$. The disease is especially harmful for young (pigs up to one year old). The intensity of their infestation can reach several hundred eggs in $1 \mathrm{~g}$ of feces.

Ascaris suum Goeze, 1782 affects not only the digestive system, but also the respiratory system. Infestation can cause intestinal disorders; high intensity of infestation among piglets causes intestinal blockage, rupture, therefore peritonitis and death. Hepatopulmonary migrations of $A$. suum lead to liver disorders and bronchopneumonia (Bila, 1999; Evstafieva, 2010). According to Ponomar and Soroka (2008), helminths produce special substances, which prevent the proliferation by T- and B-lymphocytes. Under the influence of helminths' antigens, a great number of T-suppressors appear in the host's organism, which decreases the activity of other subpopulations of T-lymphocytes. This leads to development of immunological tolerance among young pigs. Deficiencies in the immune system are a key factor which determines the onset and duration of the invasive process. Nematodes block the host's defense processes. One of the mechanisms of such immunosuppression is the phenomenon of antigen competition, when T-lymphocytes, which were activated by the helminths' antigens, suppress the ability of B-lymphocytes to produce antibodies to antigens of other infestation agents. This explains the complications during the infection process of $A$. suum infestation and the decrease in the level of postvaccinal immunity against infections, and often causes collapse in the immune system (Ponomar and Soroka, 2008).

Today, scientists all around the world are developing methods of utilization of swine manure, its disinfection, elimination of eggs of A. suum in the environment, and treatment of pigs against ascariasis. Recently veterinary specialists have tended to prefer complex injectional antihelmintic preparations, which are efficient both against endo and ectoparasites, and also against different stages of helminths' development. In this respect, preparations of macrocyclic lactone, which are efficient against nematode infestation, appear to be promising. Also there are antihelmintic preparations, which are efficient both at the larval and mature stages of parasites' development. Many Ukrainian and foreign authors (Belœil et al., 2003; Veneziano et al., 2004; Fthenakis et al., 2005; Gudkova et al., 2006; Antipov, 2010; Artemenko, 2011) have reported the high antihelmintic efficiency of preparations of the benzimidazole group (albendazole, phenbendazolum). A number of researchers have conducted experiments on the influence of herbal preparations and flavourings upon the viability of nematode larvae (Chiang et al., 2005; Sato et al., 2006; Somolinos et al., 2008; Si et al., 2009; Belletti et al., 2010)

\section{Materials and methods}

In the experiment, we used fresh eggs of $A$. suum nematodes from swine feces, taken from farms in Dnipropetrovsk region. Samples of pigs' feces were delivered in plastic containers at the temperature of $+17 \ldots+19^{\circ} \mathrm{C}$ to the laboratory of the Parasitology and Veterinary-Sanitary Examination Department at the Dnipro State Agrarian-Economic University. At the beginning of experiment, A. suum eggs (Fig. 1) were detected by the McMaster method (Pereckiene et al., 2007; Zajac et al., 2011). A thick brown tuberous shell is typical for these eggs. Females of this nematode species lay 
grey eggs in the small intestine. During their way through the intestines, they obtain a brown colour due to the feces. The eggs detected were not mature: inside they had bleached blastomeres in the process of fragmentation, which is typical for eggs of this species of nematode. Average intensity of $A$. suum infestation in the selected material was 475 eggs/g of feces. Later in the study, swine feces were weighed by portions of $10 \mathrm{~g}$. The samples were put in glasses, by addition of water, the eggs of $A$. suum were "washed" from the feces. The "washed" eggs were then put in a Petri dish and left for 21 days in a thermostat at the temperature of $+28{ }^{\circ} \mathrm{C}$ for cultivation of larvae inside the eggs before the infestation stage (Fig. 2). Such eggs contained sedentary larvae, twisted in form larvae. At the same time, for preventing the breeding of bacteria and fungi in the sample, $2 \%$ solution of formalin was added. Then the solution with eggs was uniformly stirred and poured in $0.1 \mathrm{ml}$ portions into plastic test-tubes of $1.5 \mathrm{ml}$ capacity. Then $1 \mathrm{ml}$ solution of flavourings was added: cinnamaldehyde (0656 Codex Alimentarius), benzoic acid ( $\mathrm{E}_{210}$ Codex Alimentarius) and methylparaben ( $\mathrm{E}_{218}$ Codex Alimentarius). The experiment used three concentrations of the substances $(10,1$ and $0.1 \mathrm{~g} / \mathrm{l})$, and also the control (distilled water); each experiment was conducted with eight replications (Fig. 3). The duration of the experiment was 24 hours at the temperature of $+22 \ldots+24^{\circ} \mathrm{C}$. The viability of the larvae in the eggs was determined by their mobility when the temperature of the fluid containing the eggs was raised to $+37{ }^{\circ} \mathrm{C}$ in the solutions of the studied substances.

\section{Table 1}

Properties and usage of flavouring agents* which were used for establishing the viability level of A. suum larvae

\begin{tabular}{|c|c|c|c|c|c|c|}
\hline \multirow{2}{*}{$\begin{array}{l}\text { Name of the } \\
\text { substance }\end{array}$} & \multirow{2}{*}{$\begin{array}{l}\text { Chemical } \\
\text { formula }\end{array}$} & \multirow{2}{*}{$\begin{array}{c}\text { Structural } \\
\text { formula }\end{array}$} & \multirow{2}{*}{ Properties } & \multirow{2}{*}{ Content } & \multicolumn{2}{|r|}{ Usage } \\
\hline & & & & & in food industry & in medicine \\
\hline Cinnamaldehyde & $\mathrm{C}_{9} \mathrm{H}_{8} \mathrm{O}$ & & $\begin{array}{l}\text { Colourless or pale-yellow } \\
\text { liquid with strong smell of } \\
\text { cinnamon }\end{array}$ & $\begin{array}{c}\text { Is present in brown and cassia essential oil, } \\
\text { and also is present in small amounts in oil } \\
\text { of patchouly, hyacinths and others }\end{array}$ & $\begin{array}{l}\text { As a component } \\
\text { of food essences }\end{array}$ & $\begin{array}{l}\text { As a fungicide, } \\
\text { insecticide }\end{array}$ \\
\hline Benzoic acid & $\mathrm{C}_{7} \mathrm{H}_{6} \mathrm{O}_{2}$ & & $\begin{array}{l}\text { White crystals, poorly } \\
\text { soluble in water }\end{array}$ & $\begin{array}{l}\text { Is present in the content of many plants } \\
\text { (about } 0.05 \% \text { in berries) and animals } \\
\text { (in the urine of mammals, } \\
\text { especially herbivores) }\end{array}$ & $\begin{array}{l}\text { When canning } \\
\text { food products }\end{array}$ & $\begin{array}{l}\text { For treating skin diseases, } \\
\text { as an external antiseptic } \\
\text { and fungicidal agenda }\end{array}$ \\
\hline Methylparaben & $\mathrm{C}_{8} \mathrm{H}_{8} \mathrm{O}_{3}$ & & $\begin{array}{c}\text { White crystalline substance } \\
\text { with a typical smell }\end{array}$ & Is found in the roots of Oxalis tuberosa & As a preservative & As an antiseptic \\
\hline
\end{tabular}

Note: * - Official Journal of the European Union, L 354/46 (2008), Sun (2007), Smirnov (2008).

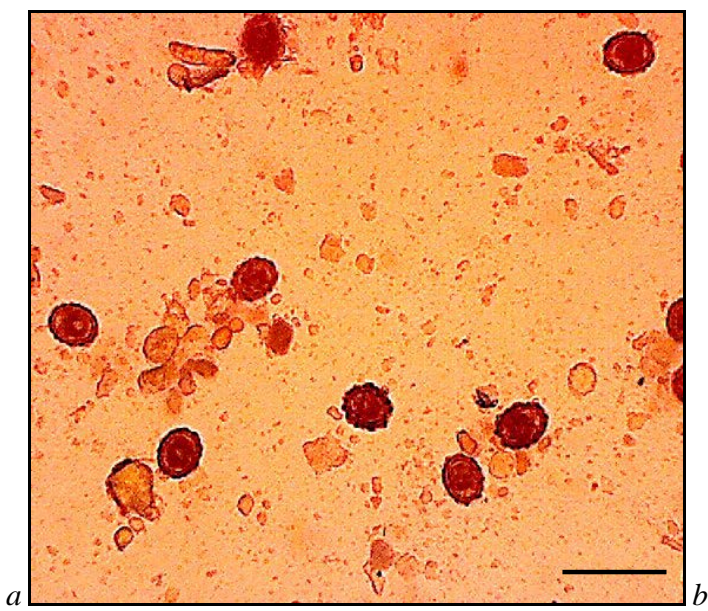

Fig. 1. Eggs of $A$. suum on the first day of the experiment: bar $=100 \mu \mathrm{m}(a)$ or $10 \mu \mathrm{m}(b)$

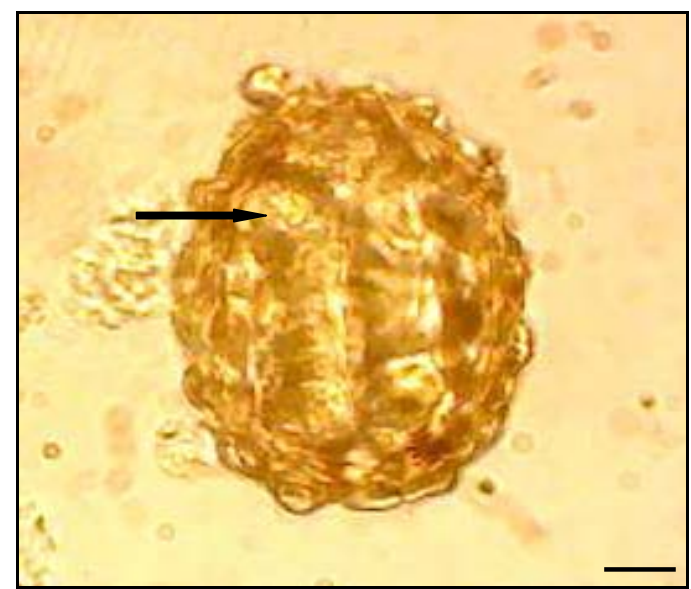

Fig. 2. Mature egg of $A$. suum on 22nd day of the experiment: pointer indicates the formed invasive larvae, bar $=10 \mu \mathrm{m}$

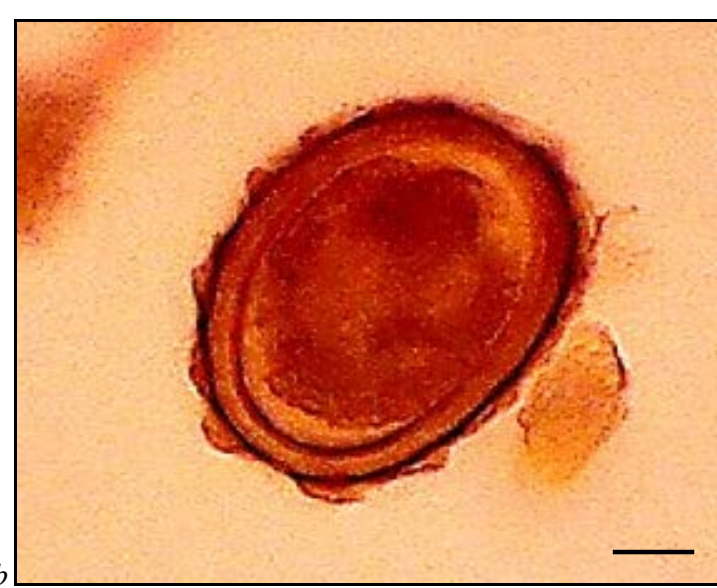

Results

Laboratory experiments on the influence of flavourings and source materials approved for use in and on foods (cinnamaldehyde, benzoic acid, methylparaben) upon the viability of larvae and eggs of nematodes indicate that the concentration of these substances significantly contributed to the mortality of parasites. After raising the temperature of fluid containing the eggs to $+37^{\circ} \mathrm{C}$ in the solution of $10 \mathrm{~g} / \mathrm{l}$ cinnamaldehyde concentration, no mobility of A. suum larvae in eggs was registered. Only $39 \%$ and $16 \%$ of A. suum larvae died under the concentrations of 1 and $0.1 \mathrm{~g} / \mathrm{l}$ respectively. $\mathrm{LD}_{50}$ for invasive eggs was $2437 \pm 864 \mathrm{mg} / \mathrm{l}$ (Fig. 3a).

Similar results were registered for pathogens of ascariasis after using benzoic acid. About 55\% of larvae in eggs survived at $1 \mathrm{~g} / \mathrm{l}$ concentration of this substance. With smaller concentrations of benzoic acid, we observed a $100 \%$ survival rate of larvae in the eggs of $A$. suum. Only at $10 \mathrm{~g} / \mathrm{l}$ concentrations of benzoic acid did $100 \%$ of eggs die. For $A$. suum at the infestation stage $\mathrm{LD}_{50}=1240 \pm$ $680 \mathrm{mg} / \mathrm{l}$ (Fig. 3b). 


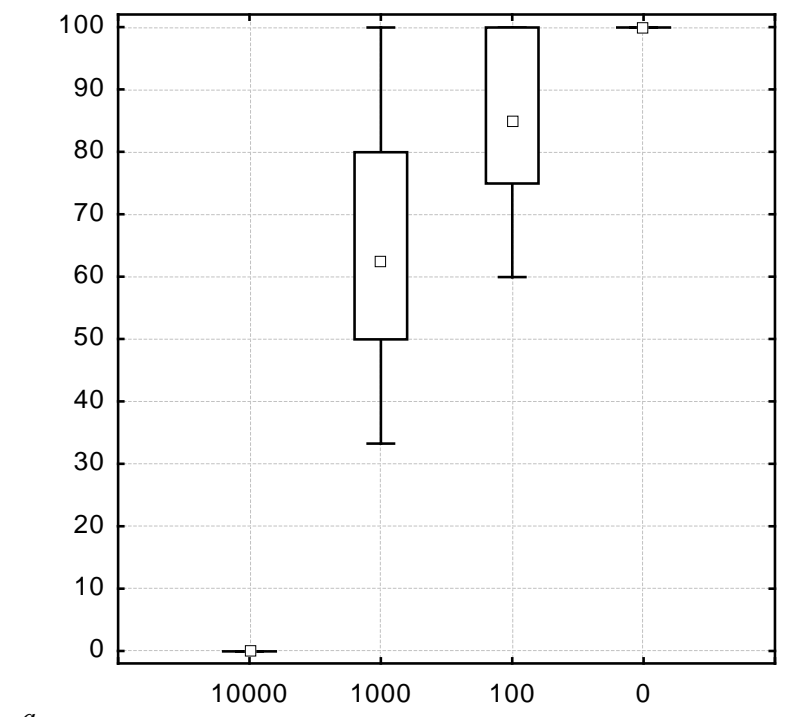

$a$

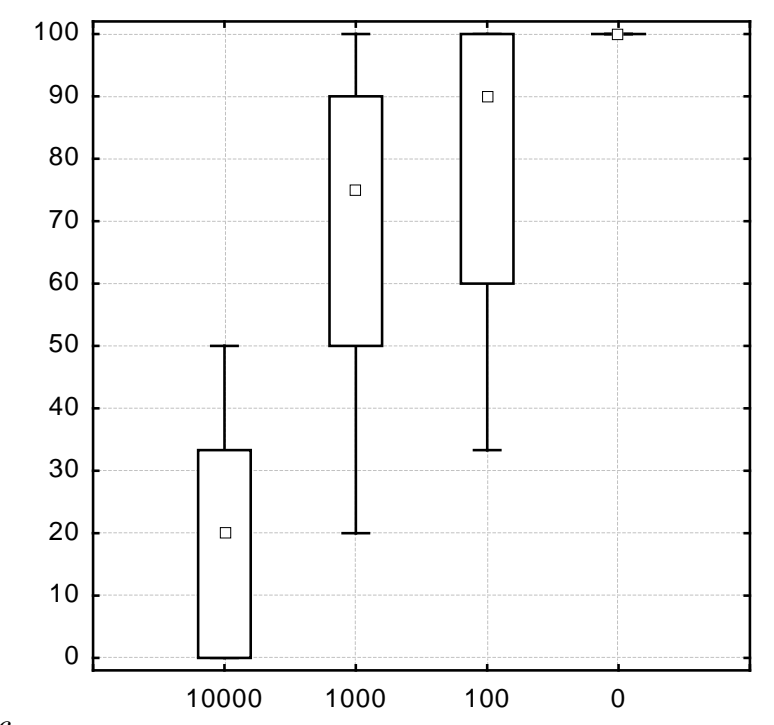

$C$

Methylparaben was the least effective. Under $10 \mathrm{~g} / \mathrm{l}$ concentration of methylparaben $20 \%$ of larvae in eggs of $A$. suum survived. At smaller concentration ( $1 \mathrm{~g} / \mathrm{l})$ the substance killed $25 \%$ of larvae in the eggs of nematodes. Methylparaben solution at $0.1 \mathrm{~g} / \mathrm{l}$ concentration killed about $10 \%$ of larvae in eggs of $A$. suum. $\mathrm{LD}_{50}$ for methylparaben at the infestation stage of $A$. suum eggs was 3 $850 \pm 2130 \mathrm{mg} / \mathrm{l}$ (Fig. 3c).

\section{Discussion}

The search for the most effective methods of controlling ascariasis of swine continues to this day. For deactivation of the eggs of these nematodes, ammonia is used (Nordin et al., 2009; Katakam et al., 2014; Fidjeland et al., 2015). The temperature of $\mathrm{NH}_{3}$ is an essential factor: increase in temperature speeds up the deactivation of $A$. suum eggs. Therefore Fidjeland et al. (2015) recommend adding urea and other alkaline material when processing feces of pigs with ascariasis, and also advise raising the temperature. Similar experiments were also conducted by Katakam et al. (2014). According to the results of their research, following an increase in temperature, the time needed to deactivate $A$. suum eggs decreased. Nordin et al. (2009) proved the lethal action of urea and temperature $+34{ }^{\circ} \mathrm{C}$ on eggs of $A$. suum. Analysis of their publications proves that the deactivation of nematode eggs in such conditions takes less than 10 days. For deactivating the eggs of A. suum in the environment, Nelson et al. (2001) recommend using a mixture of reagents: the observed deactivation was attributed

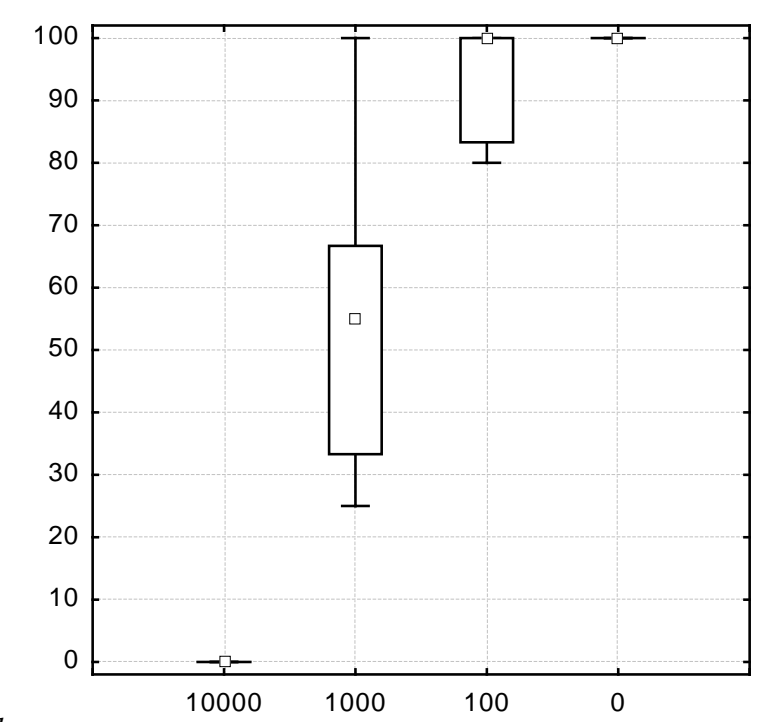

b

Fig. 3. The effect of flavourings and source materials approved for use in and on foods on the vitality of larvae in eggs of $A$. suum: $a$ - cinnamaldehyde $\left(\mathrm{LD}_{50}=2437 \pm 864 \mathrm{mg} / \mathrm{l}\right)$,

$b$ - benzoic acid $\left(\mathrm{LD}_{50}=1240 \pm 680 \mathrm{mg} / \mathrm{l}\right)$, $c$ - methylparaben $\left(\mathrm{LD}_{50}=3850 \pm 2130 \mathrm{mg} /\right)$;

along the abscissa axis - concentration of active substance (mg/l), along the ordinate - percentage of larvae which survived in the experiments during 24 hours; $n=8$

primarily to the $35 \%$ ethanol content of the acid-alcohol solution. De Velásquez et al. (2004) have reported the lethal action of ozone on the eggs of $A$. suum. Under the influence of ozone, $90 \%$ of eggs became nonviable already after the first 60 minutes. Another $10 \%$ of the number of surviving eggs died after the second hour of the experiment. The concentration of dissolved ozone in the liquid phase (in the solution of feces) was from 3.5-4.7 mg/l.

In "organic" swine rearing, the usage of chemical substances against the pathogens of infections and infestations is strictly limited. Therefore pigs in such farms are more heavily affected by A. suum infestation. "Organic" farms decrease the level of environmental contamination with $A$. suum eggs by regular mechanical cleaning of the pigs' living area from feces with further compulsory composting (Katakam et al., 2016). Katakam et al. (2014) in their experiments studied the relationship between viability of $A$. suum eggs in deep litter and the litter's humidity and temperature. At a temperature of $+43.6^{\circ} \mathrm{C}$ and relative humidity of $43 \%$ the viability of $A$. suum eggs was no higher than $5 \%$, and only $0.004 \%$ of eggs developed to the larval stage. The influence of temperature on the development of $A$. suum eggs was described by Kim et al. (2012). $A$. suum eggs were unable to develop for a month at a temperature of $5^{\circ} \mathrm{C}$. The optimum temperature for the development of eggs of this nematode species is $+35^{\circ} \mathrm{C}$ : the larvae of $A$. suum develop in eggs already on the 17th day of incubation.

Decreasing the number of $A$. suum eggs in the environment is possible not only by processing the pigs' feces. This can also be achieved by increasing the resistance of the pigs' organism by using 
a balanced diet dominated by protein. Lack of iron and also the decrease of protein content in the diet leads to malnutrition, loss of weight, decreased resistance in the pigs' organism to A. suum (Pedersen et al., 2001, 2002).

Williams et al. (2015) recommend using purified extract of Cichorium intybus Linnaeus, 1758 for phytotherapy of $A$. suum larvae. It can affect the viability of larvae of these nematodes in vitro. The extract inhibits glutathione-S-transferase activity of $A$. suum.

As an alternative to using synthetic antihelmintic preparations for decreasing the number of eggs which enter the environment through pigs' feces, and also for decreasing the level of pigs' infestation with A. suum, Kaplan et al. (2014) recommend using a mixture of essential oils: TTN1013 (a-pinene, linalyl acetate, p-cymene, and thymol octanoate) and TTN1014 (a-pinene, linalyl acetate, p-cymene and thymol acetate).

De Araújo et al. (2008) recommend using fungi-helmintophages Duddingtonia flagrans (Dudd.) R. C. Cooke, 1969, Monacrosporium sinense Xing Z. Liu \& K.Q. Zhang, 1994, Pochonia chlamydosporia (Goddard, 1913) Zare et W. Gams, 2001 with domination of the latter species for biological control of the number of $A$. suum. Similar studies have been conducted by Ferreira et al. (2011): they also showed high ovicidal activity of $P$. chlamydosporia fungi against eggs of $A$. suum.

The work of Rojas-Oropeza et al. (2016) covers the study of the influence of volatile fatty acids (VFA) of four different compounds on the viability of eggs of $A$. suum. The compounds included acetic, propionic, butyric, valeric, and isovaleric acids. The studied concentrations of these acids are often found in acidogenic anaerobic digesters. According to the results of the experiment, the viability of A. suum eggs decreased after using these acids.

The literature includes data on using flavourings not only in the food industry. These compounds are tested for bactericidal and fungicidal properties (Chiang et al., 2005; Sato et al., 2006; Somolinos et al., 2008; Si et al., 2009; Belletti et al., 2010). The antihelmintic properties of such substances have been studied earlier against Strongyloides ransomi (Schwartz and Alicata, 1930) larvae (Nematoda, Rhabditida). $\mathrm{LD}_{50}(\mathrm{x} \pm \mathrm{SD})$ for $S$. ransomi larvae in laboratory experiment: benzaldehyde $-142 \pm 64$, citral $-97 \pm$ $36 \mathrm{mg} / \mathrm{l}$ (Boyko et al., 2017). Thus, chemical compounds used as flavourings in the human diet have a certain antihelmintic potential, which needs to be studied further.

\section{Conclusions}

One of the most common parasitic diseases of pigs globally is ascariasis. Control of the ascariasis pathogen in the host's organism and in the environment is essential for the health of the animals and successful swine-rearing. According to the results of study on the effect of cinnamaldehyde, benzoic acid and methylparaben upon the viability of eggs of $A$. suum, we recommend using minimum concentration of solutions of these substances against the eggs of A. suum, at $10 \mathrm{~g} / \mathrm{l}$.

\section{References}

Antipov, N. (2010). Askaroz svynej [Ascariasis of pigs]. Propozycija, 12, 124-126 (in Ukrainian).

Araújo, J. V., Braga, F. R., Silva, A. R., Araujo, J. M., \& Tavela, A. O. (2008). In vitro evaluation of the effect of the nematophagous fungi Duddingtonia flagrans, Monacrosporium sinense, Pochonia chlamydosporia on Ascaris suum eggs. Parasitology Research, 102, 787-790.

Artemenko, L. P. (2011). Askaroz - nebezpechna invazija u svynej [Ascariasis harmful infestation of pigs]. Suchasna Veterynama Medycyna, 4, 48-52 (in Ukrainian).

Belletti, N., Kamdem, S. S., Tabanelli, G., Lanciotti, R., \& Gardini, F. (2010). Modeling of combined effects of citral, linalool and $\beta$-pinene used against Saccharomyces cerevisiae in citrus-based beverages subjected to a mild heat treatment. International Journal of Food Microbiology, 136(3), 283-289.

Belœil, P. A., Chauvin, C., Fablet, C., Jolly, J. P., Eveno, E., Madec, F., \& Reperant, J. M. (2003). Helminth control practices and infections in growing pigs in France. Livestock Production Science, 81, 99-104.
Bila, I. D. (1999). Pnevmonii' svynej, sprychyneni askaryso-mikrobnymy asociacijamy ta rozrobka profilaktychnyh i likuval'nyh zahodiv [Pneumonias of pigs caused by ascaris-microbe associations and development of prevention and treatment measures]. Instytut Eksperymental'noi' i Klinichnoi' Veterynarnoi' Medycyny, Kharkiv (in Ukrainian).

Boyko, A. A., \& Brygadyrenko, V. V. (2017). Changes in the viability of Strongyloides ransomi larvae (Nematoda, Rhabditida) under the influence of synthetic flavourings. Regulatory Mechanisms in Biosystems, 8(1), 36-40.

Chiang, L.-C., Ng, L.-T., Cheng, P.-W., Chiang, W., \& Lin, C.-C. (2005) Antiviral activities of extracts and selected pure constituents of Ocimum basilicum. Clinical and Experimental Pharmacology and Physiology, 32(10), 811-816.

De Velásquez, M. T. O., Martínez, J. L., Monje-Ramírez, I., \& RojasValencia, M. N. (2004). Destruction of helminth (Ascaris suum) eggs by ozone. Ozone: Science and Engineering, 26, 359-366.

Evstafieva, V. O. (2010). Asociatyvni invazii' svynej v umovah Lisostepu i Stepu Ukrai'ny [Associative infestations of pigs in the conditions of forest-steppe and steppe of Ukraine]. Nacional'nyj Universytet Bioresursiv i Pryrodokorystuvannja Ukrai'ny, Kyiv (in Ukrainian).

Ferreira, S. R., Araújo, J. V., Braga, F. R., Araujo, J. M., Carvalho, R. O., Silva, A. R., Frassy, L. N., \& Freitas, L. G. (2011). Ovicidal activity of seven Pochonia chlamydosporia fungal isolates on Ascaris suum eggs. Tropical Animal Health and Production, 43, 639-642.

Feshenko, D. V. (2008). Osoblyvosti epizootologii', patogenezu ta terapii' zmishanoi' nematodoznoi' invazii' svynej [Peculiarities of epizootiology, pathogenesis and therapy of mixed nematodal infestation of pigs]. Veterynarna Medycyna Ukrai'ny, 2, 18-20 (in Ukrainian).

Fidjeland, J., Nordin, A., Pecson, B. M., Nelson, K. L., \& Vinneras, B. (2015). Modeling the inactivation of ascaris eggs as a function of ammonia concentration and temperature. Water Research, 83, 153-160.

Fthenakis, G. C., Papadopoulos, E., \& Himonas, C. (2005). Effects of three anthelmintic regimes on milk yield of ewes and growth of lambs. Veterinary Medicine, 52, 78-82.

Gudkova, A. Y., Petrov, Y. F., \& Ivaniuk, V. P. (2006). Formirovanie parazitarnoj sistemy $\mathrm{v}$ organizme svinej pri nematodozah [Formation of the parasitic system in the organism of pigs with nematodes]. Veterinarija, 9, 31-33 (in Russian).

Kaplan, R. M., Storey, B. E., Vidyashankar, A. N., Bissinger, B. W., Mitchell, S. M., Howell, S. B., Mason, M. E., Lee, M. D., Pedroso, A. A., Akashe, A., \& Skrypec, D. J. (2014). Antiparasitic efficacy of a novel plant-based functional food using an Ascaris suum model in pigs. Acta Tropica, 139, 15-22.

Katakam, K. K., Mejer, H., Dalsgaard, A., Kyvsgaard, N. C., \& Thamsborg, S. M. (2014). Survival of Ascaris suum and Ascaridia galli eggs in liqui manure at different ammonia concentrations and temperatures. Veterinary Parasitology, 204, 249-257.

Katakam, K. K., Thamsborg, S. M., Dalsgaard, A., Kyvsgaard, N. C., \& Mejer, H. (2016). Environmental contamination and transmission of Ascaris suum in Danish organic pig farms. Parasites and Vectors, 9, 80.

Katakam, K. K., Thamsborg, S. M., Kyvsgaard, N. C., Dalsgaard, A., \& Mejer, H. (2014). Development and survival of Ascaris suum eggs in deep litter of pigs. Parasitology, 141, 1646-1656.

Kim, M.-K., Pyo, K.-H., Hwang, Y.-S., Park, K. H., Hwang, I. G., Chai, J.Y, \& Shin, E.-H. (2012). Effect of temperature on embryonation of Ascaris suum eggs in an environmental chamber. The Korean Journal of Parasitology, 50(3), 239-242.

Nelson, K. L., \& Darby, J. L. (2001). Inactivation of viable Ascaris eggs by reagents during enumeration. Applied and Environmental Microbiology, 67(12), 5453-5459.

Nordin, A., Nyberg, K., \& Vinneras, B. (2009). Inactivation of Ascaris eggs in source-separated urine and feces by ammonia at ambient temperatures. Applied and Environmental Microbiology, 75(3), 662-667.

Pedersen, S., Saeed, I., Friis, H., \& Michaelsen, K. F. (2001). Effect of iron deficiency on Trichuris suis and Ascaris suum infections in pigs. Parasitology, 122(5), 589-598.

Pedersen, S., Saeed, I., Michaelsen, K. F., \& Friis, H. (2002). Impact of protein energy malnutrition on Trichuris suis infection in pigs concomitantly infected with Ascaris suum. Parasitology, 124(5), 561-568.

Pereckiene, A., Kaziunaite, V., Vysniauskas, A., Petkevicius, S., Malakauskas, A., Sarkunas, M., \& Taylor, M. A. (2007). A comparison of modifications of the McMaster method for the enumeration of Ascaris suum eggs in pig faecal samples. Veterinary Parasitology, 149, 111-116.

Ponomar, S. I., Soroka, N. M. (2008). Gel'mintogematologichni ta gel'mintomamologichni doslidzhennja pry strongiloi'dozi svynej [Helminth-hematological and helminth-mammalogical studies of pigs with strongyloidosis]. Naukovyj Visnyk Nacional'nogo Agramogo Universytetu, 7, 233-240 (in Ukrainian).

Rojas-Oropeza, M., Hernández-Uresti, A. S., Ortega-Charleston, L. S., \& Cabirol, N. (2016). Effect of volatile fatty acids in anaerobic conditions 
on viability of helminth ova (Ascaris suum) in sanitization of municipal sludge. Environmental Technology, in press.

Sato, K., Krist, S., \& Buchbauer, G. (2006). Antimicrobial effect of transCinnamaldehyde, (-)-Perillaldehyde, (-)-Citronellal, Citral, Eugenol and Carvacrol on airborne microbes using an airwasher. Biological and Pharmaceutical Bulletin, 29(11), 2292-2294.

Si, W., Ni, X., Gong, J., Yu, H., Tsao, R., Han, Y., \& Chambers, J. R. (2009). Antimicrobial activity of essential oils and structurally related synthetic food additives towards Clostridium perfringens. Journal of Applied Microbiology, 106(1), 213-220.

Somolinos, M., Garcia, D., Pagan, R., \& Mackey, B. (2008). Relationship between sublethal injury and microbial inactivation by the combination of high hydrostatic pressure and citral or tert-butyl hydroquinone. Applied and Environmental Microbiology, 74(24), 7570-7577.
Veneziano, V., Rubino, R., Fedele, V., Rinaldi, L., Santaniello, M., Schioppi, M., Cascone, C., Pizzillo, M., \& Cringoli, G. (2004). The effects of five anthelmintic treatment regimes on milk production in goats naturally infected by gastrointestinal nematodes. South African Journal of Animal Science, 34, 238-240.

Williams, A., Pena-Espinoza, M., Hansen, T. A., Boas, U., \& Thamsborg S. M. (2015). Purified extracts from chicory (Cichorium intybus) inhibit Ascaris suum glutathione-S-transferase activity and reduce survival of larvae in vitro. 25th International Conference of the World Association for the Advancement of Veterinary Parasitology: Abstract Book. Liverpool, United Kingdom. P. 142-142.

Zajac, A. M., \& Conboy, G. A. (eds.) (2011). Veterinary clinical parasitology, 8th ed. John Wiley and Sons, UK. 